\title{
Missing Technology in Modern Pedagogy: Use of Technology in Modern Teaching, Learning, and Evaluation of Mathematics Curriculum
}

\author{
Vijay R Tiwari ${ }^{1 \star}$ (1)
}

${ }^{1}$ Jai Hind College, INDIA

${ }^{*}$ Corresponding Author: vijay.tiwari@jaihindcollege.edu.in

Citation: Tiwari, V. R. (2020). Missing Technology in Modern Pedagogy: Use of Technology in Modern Teaching, Learning, and Evaluation of Mathematics Curriculum. International Journal of Pedagogical Development and Lifelong Learning, 1(1), e02005. https://doi.org/10.30935/ijpdll/8344

\begin{abstract}
In Last few decades, technological advancement has played a vital role in development of modern education system. Access of information has become simpler due to availability of internet and different operating system. Innovative techniques like virtual classrooms and laboratories are vital tool today. Mathematical software's and Mobile learning applications have not only helped in visualizing abstract concepts but also created a considerable interest in learners. Some e-platforms like Google classroom, modular object-oriented dynamic learning environment (MOODLE), Canvas classrooms, etc., have proven to be effective in connecting with students outside the classroom and evaluating them in different ways. To understand the popularity, availability, and utility of these resources among the students and teachers, author conducted an online survey and found some important relations using statistical techniques. The survey interview was conducted with 50 students of under graduation level and 10 students of post-graduation level. Students were surveyed form 10 different institutions. Eighteen Mathematics Faculties with experience ranging from three to thirty years were interviewed. The details and interpretations of survey statistics is discussed in this paper. The author presented part of this paper under the title 'From chalk and talk to modern mock' at the first inaugural conference of mathematics teachers association(MTA-I), held at Tata Institute of fundamental research-Homi Bhabha centre for science education (TIFR-HBCSE), Mumbai, India between 3-5 January, 2019. Some innovations required to make mathematics simpler for students of all caliber is discussed in this paper.
\end{abstract}

Keywords: evaluation, higher-education, learning, teaching

Received: 6 May 2020 • Accepted: 8 Jun. 2020

\section{INTRODUCTION}

Mathematics is a subject that has been appealing and fascinating to many but abstruse and ambiguous to a considerable number of people. Thus, it becomes a great responsibility of a mathematics teacher to learn and adopt various methods to improve and upgrade their pedagogical skills from time to time.

Khongji and Nongbsap have discussed innovative methods like Induction-Deduction, Analytical-Synthetic teaching, Play-Way and certain laboratory method. These methods along with teaching aid like charts, manipulative, etc. has brought remarkable results in school and college level teaching.

The new generation students have a different expectation and demand therefore there is a requirement of new resources and techniques. Teachers can meet these expectations by using technological aid in their lectures.
Due to development of various massive open online course (MOOC) platforms, students are able to explore their subject beyond the boundaries of classroom teaching. Nowadays, students and teachers are acquiring number of skills through online courses. Modern classrooms made of interactive boards, tablet PC are slowly replacing the old classrooms.

Various program in mathematics offer courses on software to enhance the computational and research skills of students. With the advent of mobile learning applications, learning process has become much faster than it was a decade before. In very near time school bag packs will be replaced by mobile phones and tablets everywhere in the world.

This paper gives the survey statistics of awareness, utility, and requirement of these resources among students in student survey report section and among teachers in teacher survey report section. Further relations between popularity of mathematical software and mobile application with the graduation level of students are obtained by using Chi-Square test to the data obtained. 
Table 1. Student's response on e-facilities in their institution

\begin{tabular}{ccccc}
\hline & $\begin{array}{c}\text { No. Of } \\
\text { Responses }\end{array}$ & $\begin{array}{c}\text { Yes, } \\
\text { Needed }\end{array}$ & NO & Available \\
\hline Online Bridge Courses & 57 & 46 & 11 & 00 \\
\hline Webinar & 53 & 42 & 03 & 08 \\
\hline $\begin{array}{c}\text { Departmental Digital } \\
\text { Library }\end{array}$ & 55 & 24 & 31 & 00 \\
\hline $\begin{array}{c}\text { Courses on } \\
\text { Mathematical software }\end{array}$ & 59 & 46 & 13 & 00 \\
\hline
\end{tabular}

With the modernization of teaching learning process there is an equal need to modernize evaluation system, especially in colleges practicing continuous evaluation process. Mobile applications can be a fast and handy tool in conducting small test and maintaining their records. At some institutions these resources are tested and implemented but the number is small. The statistics of teachers using them is presented in this paper.

\section{STUDENT SURVEY REPORT}

In the interview of 60 students, 50 were studying in undergraduate level [First Year (18) + Second Year (18) + Third Year (14)] and remaining 10 were pursuing their post-graduation in mathematics. At most 10 samples per institution were taken from undergraduate group and maximum 05 samples per institution were taken from post graduate group in order to cover maximum institutions. The number of students covered in survey decreases with increase in graduation level as the number of institutions offering specialization in mathematics in higher class reduces.

One of the major quests of this survey was to know the preference of a student for clarification of doubts. Out of 60 responses, 30 took help of online videos and online study material whereas 30 liked approaching their teachers, thus showing the equal need of online resources for self-study. Moreover, best strategy can be a teacher suggesting video lectures as a part of assignment.

It was observed that out of 58 students 18 connected with their teachers on online platforms for discussion and study material, whereas 18 were unaware and 22 were aware but were not using them. A best way to gain maximum utility is by introducing them to students from high school level.

Since language act as a barrier in understanding a lecture therefore students were asked about the idea of providing video lectures of their teacher in other local languages on difficult topics. Out of 59 responses, 21 wanted lectures in local languages, 35 in English, and 3 students said they may not refer. Therefore, these provisions are also important.

The study involved questions on having online bridge courses before commencement of a course, availability of digital library in department, webinar (online discussion clubs) with faculties and students of premier institutions, and courses on mathematical software courses. The statistics of these responses is given in Table 1.

From the data it is evident that there is big need of providing these facilities which are missing even in big cities of country. Students were asked about effectiveness of interactive boards, power point presentations, and other teaching tools in classroom. Out of 60 responses, 49 said it is effective as it is different from usual chalk and talk therefore more interesting.
Table 2. Student's response on awareness and use of Software and mobile application in Learning

\begin{tabular}{cccccc}
\hline & Level & $\begin{array}{c}\text { No of } \\
\text { Responses }\end{array}$ & Yes & $\begin{array}{c}\text { No but } \\
\text { aware }\end{array}$ & Unaware \\
\hline Mathematical & UG & 50 & 07 & 16 & 27 \\
\cline { 2 - 6 } Software & PG & 10 & 05 & 01 & 04 \\
\hline $\begin{array}{c}\text { Mobile Learning } \\
\text { Applications }\end{array}$ & UG & 49 & 21 & 14 & 14 \\
\cline { 2 - 6 } & PG & 10 & 05 & 01 & 04 \\
\hline
\end{tabular}

UG $=$ Under-Graduate PG $=$ Post-Graduate

Table 3. Contingency Table for the use of Mathematical Software

\begin{tabular}{cccc}
\hline Level & Yes & No & Total \\
\hline Undergraduate & 7 & 43 & 50 \\
\hline Postgraduate & 5 & 05 & 10 \\
\hline Total & 12 & 48 & 60 \\
\hline
\end{tabular}

Table 4. Contingency Table for the use of Mobile Application

\begin{tabular}{cccc}
\hline Level & Yes & No & Total \\
\hline Undergraduate & 49 & 01 & 50 \\
\hline Postgraduate & 10 & 00 & 10 \\
\hline Total & 59 & 01 & 60 \\
\hline
\end{tabular}

\section{Software and Mobile Learning Application}

Students were asked about their awareness and utility of mathematical software's and mobile applications in learning, details of which is given in Table 2 .

Verma (2012, p. 76), describes the method to test independence of attributes from a $\times$ c contingency table using Chi-Square test.

Using this method, a Chi Square test at 95\% level of significance was performed to test whether the use of mathematical software and mobile applications for learning is independent of graduation level of a student or not. Details of these relation are discussed in subsections below.

\section{Test of independence of mathematical software utility based on graduation level}

From the data in Table 3, the expected frequencies are $\mathrm{E}(7)=$ $10, \mathrm{E}(43)=40, \mathrm{E}(5)=2, \mathrm{E}(5)=8$. Therefore, $\chi_{\{\mathrm{cal}\}}^{2}=6.75$ and at $95 \%$ level of significance with 1 degree of freedom $\chi_{\{0.05\}}^{2}(1)=3.84$. Since $\chi_{\{\mathrm{cal}\}}^{2}>\chi_{\{0.05\}}^{2}(1)$, the null hypothesis that use of software is independent of graduation level gets rejected strongly.

A major reason for this is that most of the undergraduate program do not offer courses on mathematical software.

\section{Test of independence of mobile learning applications utility based on graduation level}

From the data in Table 4, the expected frequencies are $\mathrm{E}(49)=$ $49.167, \mathrm{E}(1)=0.833, \mathrm{E}(10)=9.833, \mathrm{E}(0)=0.167$. Therefore $\chi_{\{\mathrm{cal}\}}^{2}=0.2035$ and at $95 \%$ level of significance with 1 degree of freedom $\chi_{\{0.05\}}^{2}(1)=3.84$. Since $\chi_{\{\text {cal }\}}^{2}<\chi_{\{0.05\}}^{2}(1)$, the null hypothesis that use of software is independent of graduation level gets accepted.

Therefore, it is evident that mobile learning applications are best source to reach students of any level in graduation. 
Table 5. Teacher Response on awareness and use

\begin{tabular}{ccccc}
\hline & $\begin{array}{c}\text { No. Of } \\
\text { Responses }\end{array}$ & Yes, Needed & No, Aware & Unaware \\
\hline $\begin{array}{c}\text { Use of } \\
\text { Mathematical } \\
\text { Software }\end{array}$ & 18 & 07 & 09 & 02 \\
\hline $\begin{array}{c}\text { Use of Mobile } \\
\text { Applications }\end{array}$ & 18 & 08 & 05 & 05 \\
\hline $\begin{array}{c}\text { Computer Based } \\
\text { Test Platform }\end{array}$ & 18 & 12 & $\begin{array}{c}\text { Not Available } \\
(06)\end{array}$ & -- \\
\hline
\end{tabular}

\section{TEACHER SURVEY REPORT}

Faculty of mathematics from 14 different institution with experience ranging from 3-30 years were surveyed. Maximum 2 teachers were taken from a particular institution.

Majority of these faculties had full time teaching experience between 5 to 25 years in undergraduate level. Their response on awareness and utility of software, mobile applications in teaching and evaluation is given in Table 5 .

Statistical Details of Questions on Use of E-Resources in Teaching and Suggestions

- Out of 18 responses, 14 said that the major reason of hesitation among teachers in avoiding the use of software and mobile applications in teaching process, is lack of adequate training.

- 12 recommended the need of departmental digital library whereas 06 already had provision.

- 01 use smart boards, tablet PC, Power Point Presentation, and other equipment frequently, 08 use sometimes and 09 use rarely.

- Out of 18 responses 11 agreed that online mentor cell can be an effective tool in removing mathematics fear from students.

- Out of 18 responses, 09 felt the need of inducting courses on mathematical software's in the undergraduate curriculum.

Statistical Details of Questions on Evaluation

From past few years in Mumbai University, a computer-based tes platform called on screen marking system is used for assessing theory exams of undergraduate and postgraduate courses. A question on its effectiveness was asked to which out of 17 responses, 11 agreed that it is effective as totaling error and chances of leaving a question uncorrected is avoided.
Out of 17 responses, 8 agreed that mobile applications can bring fast and easy evaluation system.

Most of the teachers said that the reason for not using computerbased test platform for examination is that, they find difficulty in inputting questions and mathematical notations. By making these platforms more user friendly and providing adequate training to teachers such problems can be solved.

\section{CONCLUSION}

It is evident from the study that awareness and utility of mobile learning applications is more among students. There is need of webinar to promote interaction and discussion which is the backbone of learning mathematics.

Providing self-recorded lectures for bridge courses can be a good supplement to a particular course. With this, teachers can acquire skills of video editing their courses and creating their own MOOC courses.

From the survey results it can be concluded that need of computerbased test platform is more to improve quality and speed of assessment process. Nowadays, most of a teacher's time is occupied in examination and assessment, thus affecting the lecture preparation time. This problem can be solved by talking help of mobile phones and evaluation devices that is being developed therefore reducing manual labor.

By saving this time from examination process teachers can devote more time in improving their course pattern as well as can learn new courses in their area, thereby creating more opportunities for their students by providing them the additional gained knowledge.

In today's time the employ-ability chances of a student can be increased by equipping them with adequate knowledge of emerging technology in their course areas which is still missing. Mathematics students in higher education level must be provided mathematical software training as part of curriculum.

\section{REFERENCES}

Khongji, P., \& Nongbsap, W. (2015). Some innovations in teaching Mathematics (At undergraduate level), International Journal of Science and Research, 4(7), 1345-1349.

Verma, J. P. (2012). Data Analysis in Management with SPSS Software (pp. 69-101). Springer Nature. https://doi.org/10.1007/978-81-3220786-3 